NBER Working Paper Series

NOTES ON THE TAX TREATMENT OF HUMAN CAPITAL

Michael J. Boskin

Working Paper No. 116

CENTER FOR ECONOMIC ANALYSIS OF HUMAN BEHAVIOR AND SOCIAL INSTITUTIONS

National Bureau of Economic Research, Inc. 204 Junipero Serra Boulevard, Stanford, CA 94305

November 1975

Preliminary; not for quotation.

NBER working papers are distributed informally and in limited number for comments only. They should not be quoted without written permission of the author.

This report has not undergone the review accorded official NBER publications; in particular, it has not yet been subultted for approval by the Board of Directors.

lhits rouearch was supported by a contract with the U.S. Treasury Depirtment ( $N o$. TOS-76-13; OS-612). Early work on this subject was supporiced by a grant to NBER from the Rockefeller Foundation. 1 hive bellefitted from comments recelved at the Treasury Conference on Tax Research. 


\section{NOTES ON THE TAX TREATMENT}

\section{OF HUMAN CAPITAL"}

Michael J. Boskin

Over the last decade and a half, economists have rediscovered the rucept of luman capital. ${ }^{2}$ The analysis of both the discrepancy between the growth of output and inputs in industrialized economies and the distribution of earnings has led economists to focus on the ecquisition of knowledge and skills by humen beings. It is now widely recognized that such human capital investments as expenditures on education, jobtraining, migration and health are an important feature of advanced economies.

While human capital has played a central role in labor economics for some time, and in growth accounting from time to time, it only rairely has crept Into the mainstream of public finance. Most analyses of tax incidence and of the efficiency properties of alternative tax devices have simply ignored human capital. Further, most analyses of human capital have simply ignored taxes. When labor economists have attempted to discuss the tax treatment of human capital, or when public financiers have attempted to incorporate human capital into the analysis () f a problem in taxation, the result frequently has been an unsupported assumption that the current tax treatment of human capital discourages

* I'his paper is part of a larger project on the taxation of humen capital. Sectlons 2 and 3 are each being expanded into more thorough treatments of Incidence and efficiency, respectively.

l. This rediscovery is frequently associated with T. W. Schultz' presidentinl address [1961], and Becker [1964]) Kiker [1966] traces the human cipital roncept. back to Pelty.

2. Sice (irilishes [1970], Becker [1967], and Mincer [1969]. 
its accumulation. For example, in his widely-heralded presidential address, T. W. Schultz asserts: ${ }^{3}$

Our tax laws everywhere discriminate against human capital. Although the stock of such capital has become large and even though it is obvious that human capital, like other forms of reproducible capital, depreciates, becomes obsolete and entails maintenance, our tax laws are all but blind on these matters.

Further, virtualiy every writer on the modern theory of optimal income taxation ${ }^{4}$ defends the assumption of an elasticity of substitution between the consumption of goods and leisure much larger than empirical studies of labor supply would suggest by invoking tax disincentives to human capital aecumulation.

While the 1ssue is bagically an empirlcal one, some light can be shed on the efflcacy of such atatements by carefully examining the ways in which taxes affect human capital accumulation. Section 1 presents a preliminary attempt at such a clarification.

If the current tax aystem, (or any proposed alternat1ve) does discourage human capital accumulation, the overall economic implications are potentially enormous. Kendrick [1979 estimates that the aggregate annual investment in human capital is of the same order of magnitude as corventionally measured savings. Any significant tax-induced decrease in human capital accumulation might result in a large decrease in output and/or redistribution of income. Section 2 outlines a simple general equilibrium model with two capital goods - physical and human - and the saving corresponding to each, to begin to deal with these isaues.

3 Bthu]tz [1961], p. 17. However, Becker [1964] and Goode'[1962] point wut the tax-1rue nature ol foregone earnings.

4 See Mirrlees [197] and Sheshinsk1 [1972] as examples. 
Once human capital is viewed as an alternative source of wealth and hence human capital investment as a source of current Baving (resources withdrawn from current congumption to help increage future output ${ }^{5}$ ), the old 1ssue of the differential tax treatment of alternative types of capital arises. 6 sensible tax policy with respect to the taxation of either physical or human capital must take into sccount the tax treatment of the alternative asget. Section 3 outlines some points of departure for auch an analysis.

5 Recognized quite gome time ago by Abramovitz [1956].

6 Discussed in detall in the stat1c case by Harberger [1966]. 
1. Does the Current Tax Treatment Discourage

Human Capital Investment?

As noted above, when the effecta of the current tax treatment of human capital is discussed, the presumption appears to be that a large disincentive to such investment exists. Certainly this has never been documented empirically. Nor do adherents to this view identify the real culprit in the situation. Is it the taxation of the returns to human investment at a positive rate? Is it the progressive rate structure of the personal income tax? Is it the fallure to allow educational expense deductions? Is it the income effect of the tax combined with differential public and private marginal propensities to invest in human capital?

While the effects of the personal income tax on human capital investment depends upon all of these detalls, we begin by focusing on what we believe to be the single most important feature of the relation between human capital investment and the tax system, nomely that the bulk of such investments are financed out of foregone earnings which are not taxed. The fallure to appreciate this basic feature of human investment is, we belleve, a source of much of the confusion on the effecta of taxes on human invegtment. 7

From Kendrick [1975], we note that roughly eighty percent of human capital investment consiats of education and informal on-the-job training; the remaining twenty percent consists of approximately equal

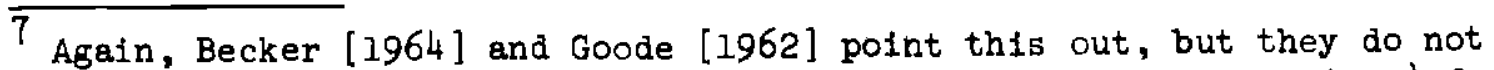
develop the implications (of the failure to tax foregone earnings) for efficiency or equity stressed below. 
amounts of mobility and health expenditures. Further, Mincer [1962] estimates that roughly forty percent of combined education and training costs are accounted for by on-the-job training. Virtually all of Job training costs. are foregone earnings as are perhaps three-fourths of higher education costs and some fraction of medical and migration costs. Thus, well over one half of human capital investment costs consist of foregone earninge. 8

Let us take on-the-job training as an example. In the early part of the typical work life, it appears that a substantial fraction of time spent on the job is devoted to training as opposed to directly productive work. While the distinction between work and investment is very difficult to make in practice, an interesting analysis by Heckman [1973] Indirectly infers that the percentage of time spent training may be as high as thirty or forty percent in the early years of labor market experience and declines toward zero over perhaps twenty years or so. Hence, a typical young worker earning $\$ 10,000$ per year may be directly working only two-thirds of the time, being paid at an annue, rate of $\$ 15,000$ and buying back one-third of his time for training (acquisition of skills) for $\$ 5,000$.

How is this $\$ 5,000$ human capital investment taxed? The worker's true income is $\$ 15,000$; at a flat tax rate of $t$, with no depreciation of the human capital investment, the worker pays a tax of $\$ 15,000 t$. Since the $\$ 5,000$ in human invegtment is financed out of foregone earnings

8 of course, this percentage also may be influenced by tax considerations. 
which are tax-free, the worker's actual tax payment is $\$ 10,000 t$. The failure to tax foregone earnings is thus equivalent to an immediate write-off of the investment cost.

In the absence of an income tax, the worker would engage in onthe-job training up to the point where the incremental investment cost just matched the present value of expected future returns. In our example, the $\$ 5,000$ cost must be matched by at least a present value of $\$ 5,000$ in expected future returns from the investment. The imposition of a tax at a flat rate $t$ on the income from the investment reduces the net return by one-third; the instantaneous write-off reduces the tax liability by one-third (at the margin). The present value of the depreciation deduction equals the cost of the investment and if the training was a profitable investment with no tax, it is still profitable in the presence of the tax-free foregone earnings .

More formally, the prospective investor in job training purchases an asset - skill, knowledge, etc. - costing $C$ and yielding an incremental income stream $Y_{t}$ - The present discounted value of the job training before the imposition of an income tax is just

$$
\int_{t=t_{0}}^{t} Y_{t} e^{-r t} d t \quad-C
$$

9 See E. C. Brown [1948] for a discussion of the neutrality of immediate depreciation (plus loss offsets) of physical capital. Also see White and White [1974] for a comparison of expensing and economic depreciation. 
where $r$ is the rate of interest. When the asset is purchased with foregone earnings, the net return to investing in the training (or other human capital investment so financed) is simply

$$
(1-t) \cdot\left(\int_{t=t_{0}}^{t=65} y_{t} e^{-r t}-c\right) .
$$

If the investment was worth undertaking in the no tax situation, it ig st1ll worth undertaking and a flat rate income tax which does not include foregone earnings in the tax base does not discourage human capital investments financed out of foregone earnings.

The major human capital investment cost which is not tax exempt Is the direct cost of education, 1.e. tuition, books and related expenses. It is these expenses which have recelved the most attention in the public finance literature. The argument has been that such expenditures are a valid cost of earning income and should be deductible either when made or depreciated throughout the working $11 \mathrm{fe}^{10}$ While true economic depreclation of educational expenses would be nondistortionary (since under true economic depreciation the differential equation describing the value of human capital is independent of the tax rate, the value of the 11 invertment would not be affected by the tax) it is not the only way to achieve neutrality. Indeed, any tax which between 1ts interest deduct1-

\footnotetext{
${ }^{10}$ See Goode [1962] for a discussion of these 1ssues. Frequently 1gnored is the lack of taxation on the human capital gain during education; 11 this tax is postponed until the income atream is realized. See Stiglitz [1975]. Indeed, this discussion closely follows his discussion of tax depreciation of physical capital.
} 
bility and depreciation allowances yields a deduction whose present value equals the investment cost is neutral. While I would be the last to argue that capital markets work perfectly, particularly in financine human investment, a modest fraction of higher education expenses are financed by borrowing and at least the interest on this debt is deductible against future income.

In analyzing when tax depreciation of educational expenses would be neutral it is important to note that many students investing in education have little other income and hence would not benefit f'rom immediate write-of' of out-of-pocket educational expenses. Unless they were allowed to carry such a write-off forward for a considerable period, the present value of the depreciation allowance will fall short of the present value of the tax liability on the return to the investment and hence will discourage investment in education. The progressive rate structure of the personal income tax acts in an analogous manner and not just on educational investments. Any. human capital investment which increases future earnings enough to drive the taxpayer into a higher tax bracket (after accounting for income averaging provisions) may decrease the ratio of the present value of the depreciation allowance to the present value of the incremental tiax liablitity. Investments which are profitable at the current tax rate

\footnotetext{
12. Given the exemptions and deriuctions in the Income tax.
} 
may not be so when account is taken of the increased future tax rate. In the on-the-job training example noted above, the worker will require a before tax expected present value of increased earnings of $\$ 3333 /(1-t$ ') where $t^{\prime}$ is the new (presumably higher than one-third) marginal tax rate. If the new rate is forty percent, he requires an increase of $\$ 5555$ in present value terma, or about eleven percent more than with the unhanged tax rate.

In addition to the diatortion in the amount of the investment in human capital, the tax system also alters the composition of human investment. For example, the instantaneous depreciation of foregone earnings (relative to slower economic depreciation) favora longer-lived human investments, e.g. general, rather than job speciflc; on-the-job training.

The final source of tax distortions in human investment decisions stems from the income effect of the tax. Since the tax revenue transfers resources from the private to the public sector, the isgue hinges on differential marginal propensities to invest in human capital publicly and privately. There is a subatantial amount of public human capital investment, but separating the marginal from the average propensity to invest in human capital is not easy; nor is it easy to determine to what extent the private sector adjusts its orm human capital investment decisions to the perceived public investment.

In summary, the current progressive rate atructure of the personal income tax probably creates a disincentive to accumulate human capital; this disincentive is perhaps most severe for secondary workers in twoearner families whose incremental incomes from human investment may gen- 
erate $a$ large increage in marginal tax rates. The lack of an educational expenditure depreclation allowance probably biases investments away from education to job training. While the extent of these distortions is primarliy an empirical matter--which forms the bulk of the research yet to be conducted--recall that a subatantial fraction of human investment is exempt from tax.

Finally, we note that the optimal investment decisions of households deal simultaneously with human investment and conventional saving. A full examination of the effects of the tax system on humen investment requires an analysis of the tax treatment of physical capital and the potential substitution of physical and human capital. Indeed, intelligent tex pollcy with respect to the depreciation of physical capital should account for the special, and perhaps inevitable, tax treatment of human capital. We begin to deal with these issues below. We merely note here that the result described above, neutrality of a flat rete tax, does not hold when nonhuman cepital is introduced into the analysis. While the result depends upon the details of depreciation allowances, method of finance and interest deductibility for nonhuman captial, a tax increase may well Induce substitution of human for nonhuman capital. 
2. Tax Incidence in an Economy with Human Capital Accumulation.

Until quite recently, the typical analysis of the effects of taxes on the distribution of income has been made in a static context. Fixed stockg of capital and labor may be mobile across sectors in response to after-tax return differentials in such models, but the problem of the growth of factor supplies has been relatively ignored. A series of recent papers has refocused attention on tax-induced changes in saving, capital accumulation and the long-run distribution of income. 13 Most of these studies have adopted rather simplistic savings functions. In perhaps the most important of these papers, Feldatein [1974a] has generalized the savings behavior to allow both differential propensities to save out of wages, profits and government revenue and a potentially interest-elastic savings rate. In $[974 \underline{b} 7$, he demonstrateg that a significant fraction of a capital income tax may be shifted to labor via a decreased capital-labor (and hence wage/rental) ratio. Perhapg the most surprising although in retrospect quite understandable - result from his work is that in the long-run the elasticity of the supply of labor is totally irrelevant in determining the incidence of the

\footnotetext{
13 See Diamond $\angle 1970]$, sato $\angle \overline{196} \bar{Z} /$, Kryzyaniak $\angle \overline{196} \bar{J}$, and Feldstein $\langle 1974 \underline{a}]$ and $\langle 1974 \underline{b}]$.
} 
tax. This occurs because of the usual assumption of a constant returns to scale technology under which only the rate of growth of the labor force, not its size at any point in time, affects the wage/rental ratio.

While these models of long-run tax incidence have not yet been totally assimilated in the teaching and practice of public finance, I believe it is important to extend such models to account for the second - and quantitatively equally as important type of capital accumulation in advanced economies: investment embodied in the knowledge and skills of the labor force. In models designed to examine the long-run incidence of a tax, we would do well to adopt a more general view of the supply of labor, defining it not just as total person-hours of work but in its envelope sense, subsuming human capital investments.

From this perspective, the rate of growth of the effective, or quality-corrected labor force, may be affected by taxes. Indeed, a tax which lowers the after-tax rental rate on human capital, such as an income or payroll tax, given the rate of interest and the price of any purchased inputs in human capital production, will decrease human capital investment ${ }^{14}$ unless an appropriate depreciation policy is followed. ${ }^{15}$ This in turn 
will drive up the ratio of physical to human capital and the ratio of unit rental rates of men to machines. In symmetry with the result of Feldstein quoted above, taxes on human capital, i.e. taxes on earninga, may be shifted in part to owners of physical capital. While I am still in the process of experimenting with alternative forms of representing this phenomenon in a simple general equilibrium setting, let us sketch out some of the basic consideration. This is done most readily by taking the Feldstein model as our point of departure and making oome simple additions.

Following Griliches $[1970]$, we define a constant return to scale production function of physical capital, $K$, and qualitycorrected labor, EN, where $\mathrm{N}$ is the number of workers and $\mathrm{E}$ is a labor-augmenting quality multiplier:

$$
\mathbf{Y}=\mathrm{F}(\mathrm{K}, \mathrm{EN})
$$

Physical capital accumulation, convential saving, and human capital accumulation follow:

$$
\begin{aligned}
& \dot{K}=s Y-\delta K \\
& \dot{E}=h \frac{Y}{N}-\delta^{\prime} E
\end{aligned}
$$

where $\delta$ and $\delta^{\prime}$ are depreciation rates and $\mathrm{s}$ and $\mathrm{h}$ represent 
saving rates, for physical and human capital.

The population grow日 exogeneously at rate $\mathrm{n}$ :

$$
\frac{\dot{N}}{N}=n
$$

Letting $I=E N$, and defining capital accumulation net of depreciation, we have

$$
\begin{aligned}
& \dot{Y}=F(K, L) \\
& \dot{K}=S Y \text { and } \\
& \dot{L}=h Y+n L
\end{aligned}
$$

Factors are paid their respective marginal products:

$$
\begin{aligned}
& \mathrm{F}_{\mathrm{k}}=r\left(1+\mu_{\mathrm{K}}\right) \\
& \mathrm{F}_{\mathrm{L}}=\mathrm{w}\left(1+\mu_{\mathrm{L}}\right)
\end{aligned}
$$

where $r$ and $w$ are after-tax factor returns and $\mu_{i}$ is the rate of tax on factor 1 .

Following Feldstein $\overline{\angle 1974 a}$ and $1974 \underline{b} /$, we allow saving to respond to its rate of return; however, each type of saving will depend upon the returns to each type of saving:

$$
\mathbf{s}=\mathbf{s}(r, w)
$$

16 Conlisk M970 7 uses this model to discuss the residual in growth accounting. single individual. Uncertainty is ignored in the present discussion, but hedging away from the relatively more uncertain factor income is potentially important. 


$$
\begin{gathered}
-15- \\
h=h(r, w)
\end{gathered}
$$

Where $r$ and $w$ are returns to physical and human capital, respec18 tively.

Again, following Feldstein, we also allow short-run labor supply to respond to its return:

$$
L=I(w) \cdot N
$$

Finally, the equilibrium growth path requires $\frac{\dot{L}}{L}=\frac{\dot{K}}{K}$, so

$$
\text { sLY }=h K Y+n K L \text {. }
$$

This system of equations can be transformed (via substitution and total differentiation) into a system of linear equations in which $d w$ and $d r$, the change in the returns to human and physical capital, are a function of the tax ratesand saving and human capital accumulation propensities, their rateof-return sensitivities and the parameters of the production technology, i.e.

$$
\begin{aligned}
& d w=f\left(s, h, s_{r}, s_{w}, h_{Y}, h_{w}, \sigma, \alpha v_{L}, \mu_{K}\right) \\
& d r=g\left(s, h, s_{Y}, s_{w}, h_{r}, h_{w}, \sigma, \alpha, \mu_{L}, \mu_{K}\right)
\end{aligned}
$$

18 We allow our notation to slip here, confusing rates of return and rental prices. An additional unit of human capital earning $w$ at each point of $t$ ime from $t$ to $T$ has a marginal rate of return of $w\left(1-e^{-r}(T-t)\right)$, where $r$ is the intereat rate. 
where subscripts denote partial derivatives, $\sigma$ is the elasticity of substitution in production and $\alpha$ labor's share in production.

The incidence of the tax may be inferred from the change in the returns to physical and human capital. The important point to note is that the "long-run" supply of labor and the sensitivity of human capital to its return, do affect the incidence of the tax.

It is also important to note that even if human capital accumulation is own rate-of-return inelastic, or if tax policy appropriately neutralizes the direct effect ot the tax on the rate of return to human investment, a more general savings behavior allowing differential public and private propensities to invest in human capital would suffice to render human capital accumulation important in the analysis of long-run tax incidence.

Let me conclude this sectionby noting the woefully inadequate empirical information upon which to approximate long-run tax incidence. While we have a fairly decent handle on the parameters of the production function, we have very little information usable in obtaining a rough guide to the conventional saving and human capital accumulation equations. We have 
virtually no information on the latter (indeed, an estimate of the annual investment can be obtained only indirectly); on the former, a renewed interest has emerged, but inclusion of the interest rate in consumption functions or savings equations is the exception, rather than the rule. Worse yet, use of the nominal rather than the real interest rate quite likely biases the result toward a zero interest elasticity.

Thus, an improved set of estimates of savings functions and a (any? ) set of estimates of human capital accumulation equations, as well as a better grasp on government saving and human investment, are essential to shed some light on long-run tax incidence. 
3. Some Brief comments on Optimal Capital Accumulation

In Section 1 above, we focused on some of the ways the tax system affected directly the accumulation of human capital; in Section 2, we introduced physical capital as well and outlined a model of long-run tax incidence. We return now to the question of efficient capital accumulation when we account simultaneously for physical and human capital accumulation.

Congider the problem of maximizing social welfare measured as the discounted sum of individual utilities:

$$
V=\int_{0}^{\infty} c^{-\infty t} P_{t} \quad U \quad\left(c_{t}\right) d t
$$

subject to the constraints

$$
\begin{aligned}
& \dot{K}=\mathbf{s F}(\mathrm{K}, \mathrm{L}) \\
& \dot{\mathrm{L}}=\mathrm{hF}(\mathrm{K}, \mathrm{L})+\mathrm{n} \mathrm{L}
\end{aligned}
$$

where $\quad c_{t}=\left(1-s_{t}-h_{t}\right), F\left(k_{t}, I_{t}\right)$

$$
\mathbf{N}
$$

and

$$
\begin{aligned}
& s_{t}, h_{t} \geqslant 0 \\
& s_{t}+h_{t}<1 .
\end{aligned}
$$

Given initial stocks of physical and human capital, we may apply the maximum principle to this problem by defining the present value of the Hamiltonian as: 
$\phi\left(k_{t}, L_{t}, s_{t}, h_{t}, q_{t}, v_{t}, t\right)=$

$$
\begin{gathered}
e^{-\nabla t} \quad\left\{P_{t} U\left(c_{t}\right)+q_{t} B_{t} F\left(K_{t}, L_{t}\right)+\right. \\
v_{t}\left(h_{t} F\left(K_{t}, L_{t}\right)+n_{I}\right)
\end{gathered}
$$

Where $e^{-\rho t} q_{t}$ and $e^{-\rho t} v_{t}$ are the auxiliary variables associated with the differential equations defining capital accumulation. Necessary and sufficient conditions for a maximum are the following :

$$
\begin{aligned}
& \dot{\mathrm{k}}=s_{t} F\left(k_{t}, L_{t}\right) \\
& \dot{H}=h_{t} F\left(k_{t}, L_{t}\right)+n L \\
& \left.\dot{q}_{t}=\bar{L}-s_{t} F_{k-} / q_{t}-h_{t} F_{k} v_{t}-\left(1-s_{t}-h_{t}\right) U_{c} F_{k}>0\right) \\
& \dot{v}_{t}=\overline{L p}-h_{t} F_{L-} / v_{t}-s_{t} F_{L} q_{t} \\
& q_{t}=U_{c} \\
& v_{t}=U_{c}
\end{aligned}
$$

Where subscripts denote partial differentiation. Substituting and rearranging, we have:

$$
\begin{aligned}
& \frac{\dot{c}_{t}}{c_{t}}=\frac{F_{k}-\rho}{\sigma} \\
& \frac{c_{t}}{c_{t}}=\frac{F_{L}-\rho}{\sigma}
\end{aligned}
$$

20 I spare the reader the laburious proof of this proposition. 
Where $\sigma=-c U_{c c} / U_{c^{\prime}}$ the elasticity of marginal utility. It is thus: obvious that optimality requires

$$
\mathrm{F}_{\mathbf{k}}=\mathrm{F}_{\mathrm{L}} \text {, }
$$

i.e. the marginal efficiency of physical and human capital must be equal. This result hardly should be surprising; it is precisely analogous to the usual efficiency rule of equalizing gross-of-tax rates of return on physical capital in all uses. Again in analogy with the usual treatment of the physical capital stock, owners of capital will respond to net-of-tax rates of return in making their investment choices. It is thus inappropriate solely to examine the tax treatment of physical capital, or of human capital, in isolation. The tax treatment of each must be examined simultaneously.

While a detailed analysis of this proposition is beyond the scope of these notes a few general remarks will serve to illustrate some of its implications. First, it is obvious that our tax system through exclusion, preferences, maximum rates and other devices often imposes different rates of tax on income from physical and human capital accruing to the same taxpaying unit in the same year. The same taxpaying unit also faces widely different rates on the two types of income given the usual lifecycle patterng of the two types of saving and the progressive 
rate structure and limited averaging possibilities in the current personal income tax. While there may well be other social objectives served by such differentation, it does distort the composition and timing of investment choices.

Second, there may well be inherent constraints in the tax treatment of human capital which have important implications for the tax treatment of physical capital. For example, liquidity and enforceability constraints may make it extremely costly 21 to attempt to include foregone earnings in the tax base, i.e. it is likely that a large fraction of human capital investments must be tax-exempt and thus treated as if instantaneously depreciated. Even if we achieve the objective of uniform tax treatment of income from physical capital in all sectors of the economy (via whatever combination of rate structure, depreciation allowance and other devices is necessary), if the tax system uniformly lowered the rate of return of all types of physical capital relative to human capital, we would be underinvesting in physical capital. Indeed if it is the case that the tax system discriminates against physical capital relative to human capital (I suspect it does but this is a difficult proposition to establish given the wide variation in effective tax rates on alternative types of physical and human capital), a gtrong case could be made

21

See Boskin (1975) for a discussion of the inability to tax foregone earings due to household work. 
for liberalization of the tax treatment of physical capital. ". In a sequel, I w111 report on a set of optimal tax rules for the taxation of physical capital under alternative congtraints on the tax treatment of human capital. We also note that this distortion in taxation of human and physical capital is exacerbated by inflation, since human and physical capital have different proportions of tax recovery of costs via depreciation. In any event, we plan to attempt to say something empirical on this point In future research.

Finally, let me conclude with a proviso: Our entire analysis has been conducted in the usual closed economy framework. In an open economy, tax policles may be disciplined sharply by the (actual or potentia1) international movement of human, as well as financlal, capital.

22 Efficlent allocation of the total capital stock may thus directly conflict with short-run income distribution objectives. 


\section{REFERENCES}

Abramovitz, M., "Resources and Output Trends in the United States since 1870," Amer. Econ. Rev.., May 1956

Becker, G., Human Capital, Columbia University Press for NBER, 1964 .

Becker, G. Human Capital and the Personal Distribution of Income, Ann Arbor, 1967.

Ben-Porath, Y., "The Production of Human Capital Over Time," in W. Hansen, ed., Education, Income and Human Capital, NBER, 1970 .

Boskin, M., "Efficiency Aspects of the Differential Tax Treatment of Market and Household Economic Activity," Jour. Pub. Econ.. Jan. 1975 .

Brown, E. C., "Business-Income Taxation and Investment Incentives," Ch. IV in Pt. III of Income, Employment and Public Policy, Essays in Honor of Alvin Hansen, 1948.

Conlisk, J.., "Comment" in W. Hansen, ed., Education, Income and Human Capital, 1970.

Diamond, P., "Incidence of an Interest Income Tax," Jour. Econ. Theory, Sept. 1970.

Feldstein, M. "Tax Incidence with Growth and variable Factor Supply," Quar. Jour-Econ.., November 1974.

Feldstein, M., "Incidence of a Capital Income Tax in a Growing Economy with variable Savings Rates," Rev. Econ. Stud.. Oct. 1974.

Feldstein, M., "Inflation, Specification Bias and the Impact of Interest Rates" Jour. Pol. Econ., Nov. 1970

Goode, R., "Educational Expenditures and the Income Tax," in Economics of Higher Education, S. Mushlin, ed., 1962

Griliches Z., "Notes on the Role of Education in Production Functions and Growth Accounting," in W. Hansen ed.. Education, Income and Human Capital, 1970. 
Harberger, A., "Efficiency Aspects of Taxes on Income from Capital," in M. Kryzyaniak, ed., The Corporation Income Tax, 1966.

Heckman, J. "Estimates of a Human Capital Production Function Embedded in a Life Cycle Model of Labor Supply," mimeo, 1973.

Kendrick, J. The Formation and Stocks of Total capital, NBER, forthcoming, 1975 .

Kiker, B., "The Historical Roots of the Concept of Human Capital" Jour. Pol, Econ. Oct. 1966

Kryzyaniak, M., "The Long-run Burden of a General Tax on Profits in a Neoclassical World," Public Finance, 1967.

Mincer, J., "On-the-Job Training: Costs Returng and Some Implications," Jour. Pol. Econ., October 1962.

Mincer, J., "The Rersonal Distribution of Income. A Survey with Special Reference to the Human Capital Approach," Jour. Econ. Lit., 1969.

Mirlees, J., "A Exploration in the Theory of optimal Income Taxation," Rev. Econ Studies., April, 1971.

Sato, K., "Taxation and Neoclassical Growth," Public Finance, 1967.

Schultz, T.W. "Investment in Human Capital," Amer. Econ. Rev., 51. March 1961.

Sheshinski, E., "An Example of the Income Tax Schedule which is Optimal for the Maxi-Min Criterion," IMSSS Tech. Report No.74, 1972 .

Stiglitz, J., "The Corporation Tax" Tech. Report No. 162, IMSSS, Stanford, 1975.

White, M. and A. White, "Tax Neutrality of Instantaneous Versus Ecanomic Depreclat Ion," L. R. B1rd and J. Head, eds., Modern Flscal Issues: Essays 1n Honor of Carl S. Shoup, Toronto, 1974. 